\title{
Right to Life in Context of Clean Environment: It's Significance under Various Laws
}

\author{
Dr. Mohd. Yousuf Bhat ${ }^{1}$, Dr. Syed Damsaz Ali Andrabi ${ }^{2}$, \\ ${ }^{l}$ Assistant Professor, Political Science, Department of Higher Education, J\&K \\ ${ }^{2}$ College Lecturer, History, Department of Higher Education, $J \& K$
}

\begin{abstract}
Everyone likes to live in a healthy environment which is a basic human necessity. Healthy environment is a nature's gift. Air, water, and land are essential for all living beings. It has been recognized ever since Stockholm Declaration that both aspects of man's environment, the natural and man-made are essential to his well-being and to the enjoyment of basic human rights - even the right to life itself. How human rights more particularly Right to Life fare in the protection of environment? Should this human right be sacrificed for environment or the two can be mutually compatible for sustainable society? This is very delicate issue demanding deeper perspective and altruistic outlook.

This paper highlights significance of wholesome environment in context in Right to Life, which is a basic guarantee for growth and development of individual, society and nation itself. Human beings should be central concern for sustainable development, and that they are entitled to a healthy and productive life in harmony with Nature.
\end{abstract}

Keywords: Environment, pollution, sustainable development, Right to life, Laws, Court decisions

In Emile, Rousseau says:

\section{INTRODUCTION}

"We are born sensitive and from our birth onwards we are affected in various ways by our environment. As soon as we become conscious of our sensations we tend to seek or shun the things that cause them, at first because they are pleasant or unpleasant, then because they suit us or not, and at last because of judgments formed by means of the ideas of happiness and goodness which reason gives us. These tendencies gain strength and performance with the growth of reason, but hindered by our habits they are more or less wrapped by our prejudices. Before this change they are what I call Nature within us".

Rousseau rightly says that man in the 'state of nature' is in equilibrium with his environment. So long as his physical needs are easily met, his psychological capacities do not develop. Initially man is an adaptive creature. Change in his surroundings sends him towards society. Population increases, climate becomes less favourable, food less plentiful, and the equilibrium of the 'state of nature' is disrupted. Man finds it more difficult to satisfy his wants and in consequence is forced to think. Pressure of wants develops man's mental powers, which react back upon and transform his wants. In society man acquires use of his latent capacity to reason and becomes egoistic and materialistic. He thinks about his fellows, calculates their behaviour, and compares himself with them.

Mutual comparisons arouse selfish feelings, and men become dominated by amour propre "Instead of being, acting constantly from fixed and invariable principles.... we find in (him) only the frightful contrast of passion mistaking itself for reason, and of understanding grown delirious". Reason is corrupted by the very emotion and desires its development brought into existence. Man is not only transformed but distorted by social life. Once vanity arises he is faced with dissatisfaction. He acquires more wants than he can gratify and desires to excel his fellows. ${ }^{2}$ Selfishness makes man a creature very much like that described by Hobbes, one whose desires are insatiable and whose self-respect depends on the deference of others.

The problems of the environment are no longer being viewed exclusively from the angle of the pollution affecting the industrialized countries but seen rather as a worldwide hazard-threatening the planet and the whole of mankind, as well as future generations. The realization of the global character of environmental problems is attested by the progress made in understanding the phenomena that create hazards for the planet, threaten the living condition of human beings and impair their fundamental rights. These phenomena concern not only the natural environment (the pollution of water, air, and atmosphere, seas, oceans and rivers; depletion of ozone layer; climatic changes) and natural resources (desertification, deforestation, soil erosion, disappearance of certain species; deterioration of flora and fauna, exhaustion of non-renewable resources, etc.) but also population and human settlements (housing, town planning, demography, etc.) and the rights of human beings (the human environment, living, working and health conditions; conditions for their exercise and the enjoyment of fundamental rights). By means of global approach to these phenomena that takes in their 
multidimensional aspects, including their human aspects, it has become possible to move from environmental law to environmental rights, proclaimed by the 1972 Stockholm Declaration. At the time of formation of UDHR in 1948, the adverse impact of environmental harm was not much felt by the people. The prime concern of the nations was on industrialization and development of economy. Although the right to clean environment is nowhere mentioned in UDHR, but it makes some conditions or limitations with regard to rights and freedoms, such as Article 29 of the UDHR states:

1) Everyone has duties to the community in which alone the free and full development of his personality is possible.

2) In the exercise of his rights and freedoms everyone shall be subject only to such limitations as are determined by law solely for the purpose of securing due recognition and respect for the rights and freedoms of others and of meeting the just requirement of morality, public order and the general welfare in a democratic society. However from the angle of ecological approach to human rights, the UN Covenant on Economic, Social and Cultural Rights (1966) guarantees the rights to "a satisfactory standard of living" and to enjoy "the highest attainable standard of health".

The environmental dimension of human rights is recognised by the ever-increasing support for right to a healthy environment, since 1968 an increasing number of international declarations and statements have, with growing specificity recognised the fundamental connection between the environmental protection and the respect for human rights. In 1968 the UN General Assembly passed a resolution identifying the relationship between the quality of the human environment and the enjoyment of basic rights. ${ }^{3}$ This was followed in 1972 by the Landmark Stockholm Declaration, which stated that "both aspects of man's environment, the natural and the man-made, are essential to the well-being and to the enjoyment of basic rights even the right to life itself, and that "man has the fundamental right to freedom, equality and adequate conditions of life, in an environment of quality that permits a life of dignity and well-being..."4 More recently the Hague Declaration stated that "the right to life is the paramount duty of those in charge of all states throughout the world". ${ }^{5}$ With the passage of time environmental protection began to find place in the agenda of international organisations. Stockholm Conference gave an impetus to the nations to think that environment has to be protected for facilitating the right to life. Clean Environment as the right of human beings began to find a place in some regional treaties. Art. 24 of the African Charter on Human and People's Rights (1981) expressly provide that "all people have right to a general satisfactory environment, favourable to their development". In 1990 the UN General Assembly declared that "all individuals are entitled to live in an environment adequate for their health and well-being".6 The United Nations Commission on Human Rights also adopted a resolution in 1990, entitled "Human Rights and the Environment", which again reaffirmed the relationship between preservation of environment and the promotion of human rights. ${ }^{7}$ In a build-up period to the 1992 Rio Conference on Environment and Development there have been many proposals to institutionalize a right to decent environment. The Draft Earth Charter is one of them. ${ }^{8}$ The Rio declaration calls for "establishing a new and equitable global partnership through creation of new levels of cooperation among states, key sectors of societies and people" ${ }^{9}$ It demands upon states to work "towards international agreements which respect the interests of all and protect the integrity of the global environmental and development system". And finally it recognizes "the integral and inter-dependent nature of the earth, our home" ${ }^{10}$. Even though the Rio Declaration may not bind nations in the legal sense, it does oblige them morally to respect the ideas as indicators of a universal consensus about the priorities of environmentalism.

However the eventually adopted Rio Declaration relates the rights issue to the broader issue of sustainable development. This is expressed in Principle 1: "Human beings are at the centre of concerns for sustainable development. They are entitled to a healthy and productive life in harmony with nature". In contrast, the right to development is clearly spelled out. ${ }^{11}$ At the European level recognition of an environmental human right is more emphatic. The Organization for Economic Cooperation and Development ("OECD") stated that fundamental human rights should include a right to "decent" environment. ${ }^{12}$ More recent in the Charter on Environmental Rights and Obligations drafted by the United Nations Economic Commission for Europe ("UNECE"), which affirms the right of everyone to an environment adequate for general health and well-being and the responsibility to protect and conserve the environment for present and future generations. ${ }^{13}$ An important indicator of the environmental human right is the extent to which it has emerged in national constitutions.

A number of studies exist which list these constitutional provisions. ${ }^{14}$ Generally speaking they reveal that more than national constitutions, from a variety of legal traditions, include an environmental human right. ${ }^{15}$ As two commentators point out, virtually every constitution revised or adopted since 1970 has addressed environmental issues. ${ }^{16}$ One of the most frequently cited constitutional provision is from the new Brazilian Constitution, which states that: "everybody has a right to an ecologically balanced environment, an asset for common use by the people, and essential to the wholesome quality of life. This imposes upon Public Authorities and the Community the obligation to defend and preserve it for present and future generations". ${ }^{17}$ 


\section{United Nations Environment Programme:}

UNEP is an important agency, dealing with the environmental issues. It has contributed to the development of international guidelines, recommendations and norms approved by the UN general assembly. Their proposals have an influential effect though they are not legally binding. ${ }^{18}$ UNEP was explicitly created to cover a variety of environmental issues, ranging from control of air pollution and protection of the ozone layer to biological diversity. Apart from providing information about environmental quality, it also finances the protection of tropical forests, wildlife preservation and other projects. In collaboration with the World Wildlife Fund and the International Union for the Conservation of Nature and Natural resources (IUCN), UNEP launched the world conservation strategy in 1980, which aimed at preserving genetic diversity and ensuring the sustainable utilization of species and ecosystem. ${ }^{19}$ UNEP was given a broad coordination role to oversee the work carried out by other agencies in the areas of ozone depletion. ${ }^{20}$

\section{European Human Rights Bodies:}

The right to life in an essential human right with environmental aspects, although not based on environmental facts, one Council of Europe case suggests that a Government may be liable in certain circumstances for loss of life if it fails to protect its citizens from life-threatening dangers. In Pine Valley Developments Limited and Others V. Ireland ${ }^{21}$, the applicants complained that the denial by local planning authorities of permission to construct commercial buildings on their land constituted a violation of protocol I, article 1. Permission to build was denied because the area was zoned as a green belt. The court concluded that, although the planning restrictions constituted an interference with the right to peaceful enjoyment, the interference did not constitute a violation of Protocol I, article 1, because it was lawful, in pursuit of a legitimate aim and proportionate to that aim. The court stated that preventing construction "for the further development of agriculture so as to preserve a green belt must be regarded as a proper way if not the only way of achieving that aim". This case thus demonstrates that environmental concerns are encompassed within the human rights instruments. Support for the claim that government-must take positive steps to guarantee human rights is found X V. France, where the applicant alleged that Government had violated her right to peaceful enjoyment of her property by building a nuclear power plant near her home. In that case the court implied that states may have to take affirmative action to protect human rights. The Court stated that "a State has not only the duty to respect, but also to protect rights". ${ }^{22}$ The claim was ultimately declared inadmissible, but it should be noted that the claimant had already received some compensation from the Government.

\section{World Conference on Human Rights:}

The World Conference on Human Rights, held at Vienna from 14 to 25 June 1993, solemnly adopted the Vienna Declaration and Programme of Action containing 142 paragraphs on various aspects of human rights. It is worth quoting those directly related to the right to the right to development and environment. Part I, paragraphs 10 and 11 read as follows:

10. The World Conference on Human Rights reaffirms the right to development, as established in the Declaration on the Right to Development, as a universal and inalienable right and an integral part of fundamental human rights. As stated in the Declaration on the Right to Development, the human person is the central subject of development. While development facilitates the enjoyment of all human rights, the lack of development may not be invoked to justify the abridgement of internationally recognized human rights. States should cooperate with each other in ensuring development and eliminating obstacles to development. The international community should promote an effective international cooperation for the realization of the right to development and the elimination of obstacles to development. Lasting progress towards the implementation of the right to development requires effective development policies at the national level, as well as equitable economic relations and favourable economic environment at the international level."

11. The right to development should be fulfilled so as to meet equitably the developmental and environmental needs of present and future generations. The World Conference on Human Rights recognizes that illicit dumping of toxic and dangerous substances and waste potentially constituters a serious threat to the human rights to life and health of everyone. Consequently the World Conference on Human Rights calls on all states to adopt and vigorously implement existing conventions relating to the dumping of toxic and dangerous products and waste and to cooperate in the prevention of illicit dumping.

\section{Commission on Sustainable Development:}

In accordance with the provisions on international institutional arrangements of Agenda 21 adopted by the United Nations Conference on Environment and Development, and pursuant to General Assembly resolution 47/191 of December 1992, the Economic and Social Council established the Commission on Sustainable Development on 12 February 1993 (decision 1993/207). The Commission on Sustainable Development in its Fifth session (7-25 April 1997) related to "Rio Declaration on Environment and Development: application and 
implementation reviews the progress of implementation of the Principle $1{ }^{23}$ in the following way.

a) Principle 1 emphasizes the conviction of States that human beings are at the centre of environment and development and reflects, thus, an anthropocentric approach. Principle 1 reflects the fundamental human right to a life with dignity. All other principles of Rio Declaration are interpreted so as to give effect to this principle. Principle 1 is also concerned with human health, an aspect elaborated in chapter 6 of Agenda 21, paragraph 1 of which states "health and development are intimately interconnected Agenda 21 must address the primary health needs of the world's population, since they are integral to the achievement of the goals of sustainable development and primary environmental case". Paragraph 6.40 states "The overall objective is to minimize hazards and maintain the environment to a degree that human health and safety is not impaired or endangered and yet encourage development to proceed".

b) The right to a healthy environment has been frequently referred to, though often in non-legally binding instruments, and is often explicitly guaranteed and proclaimed in human rights treaty law. Since 1992, principle 1 has been recognised in treaty law. Paragraph of 1 preamble of the Desertification Convention and the Fourth Lome Convention which states that "cooperation shall be directed towards development centers on man, the main protagonist and beneficiary of development". ${ }^{24}$

c) The Programme of Action of the International Conference on Population and Development contains 14 principles also known as 1994 Cairo Principles. ${ }^{25}$ Principle 2 states: "Human beings are at the centre of concerns for sustainable development. They are entitled to a healthy and productive life in harmony with nature. People are the most important and valuable resources of any nation. Countries should ensure that all individuals are given the opportunity to make the most of their potential. They have an adequate standard of living for themselves and their families, including adequate food, clothing water and sanitation."

d) The right to a healthy and productive life in harmony with nature is often found in Constitutions and/or basic (environmental laws, formulated as a general principle of national environmental legislation. Almost all constitutions adopted or revised in the past 35 years address environmental concerns. ${ }^{26}$ Constitutional provision in a great number of states explicitly enunciate a right to a healthy environment. ${ }^{27}$ Correspondingly, almost all of the constitutions provide both an obligation of the State to conserve and a duty of the citizens to protect, the environment, the constitutional obligation on the part of the State to conserve the environment corroborates the right to a healthy environment that is in some cases formulated in terms of an individual's right to a healthy environment.

e) The supreme court of the Philippines decided that while the right to a balanced and healthful ecology is to be found under the Declaration of Principles and State Policies and not under the Bill of Rights, it does not follow that it is less important than any of the civil and political rights enumerated in the latter. Such a right belongs to a different category of rights altogether for it concerns nothing less than self-preservation and selfperpetuation, the advancement of which may even be said to predate all Governments and Constitutions. As a matter of fact, these basic rights need not even be written in the constitution for they are assumed to exist from the inception of humankind. ${ }^{28}$

The World Health Organization (WHO) In a publication entitled 'Our Planet, Our Health', ${ }^{29}$ the WHO referred to the issues of balancing rights and responsibilities with regard to right to environment. It is advanced that Governments still retain their central responsibility for protecting individuals against threats to their health and environment and should ensure that all people have access to health care and other services and resources essential to health. Governments also have a strategic role to play in promoting and supporting the initiatives of individuals, community organizations. Such governance must also ensure that short-term and long-term environmental health considerations are systematically taken into account in all developments.

\section{The Constitution of India and Clean Environment:}

In the realm of the fundamental rights the most essential right is the 'right of life' guaranteed by Article 21 of the Indian Constitution, which the article says that cannot be taken away accept according to procedure established by law. To safeguard this right and other fundamental rights we do have a very special feature in the Constitution of India known as right to constitutional remedies. Article 32 of the constitution empowers the supreme court in an appropriate proceeding to issue not only writ of mandamus, certiorari, prohibition or quo wanranto but also any other direction, order or writ for the enforcement of fundamental rights. The same power is vested in the High Courts under Article 226 of the Constitution. It is upon the exercise of this power of judicial review the Courts are called upon to decide whether any instrumentality, agency or organs of the state has transgressed or exceeded the limits of power conferred upon it and to ensure that the state and the public officials fulfill the obligation of the Constitution and the law under which they exist and function.

In addition to Chapter on Fundamental Rights, the Constitution of India contains a Chapter on Directive Principles of State Policy, which emphasize in amplification of the preamble, that the goal of Indian polity is not laissez faire, but welfare state, where the state has positive duty to ensure to its citizens social and economic justice and dignity of the individual. ${ }^{30}$ 
According to Article 48A of the Directive Principles "the State should strive to protect and improve the environment and to safeguard forests and wildlife. And Article 51A(g) of part IV-A of Fundamental Duties states that it shall be the duty of every citizen of Indian to protect and improve the natural environment. Life means to live with human dignity but if one cannot breath clean air, have safe drinking water or health food, the all human rights civil, political, social or economic are meaningless. Due to appalling scenario of the environmental pollution in our country the supreme court sharpened its tools and strategies during mid-80's and 90 's by keeping aside all technical rules of procedure and liberalised the rule of 'locus standi' in order to alleviate the sufferings of the victims of environmental pollution under the banner of Public Interest Litigation (PIL). The courts have given expanded interpretation to Article 21 concerning the right to life to include all those rights which are essential and basic for the enjoyment of the quality of life free from environmental pollution and other health and consumer hazards." ${ }^{31}$

The interpretation given by Supreme Court of India in A.K. Gopalan V. State of Madras ${ }^{32}$ Khark Singh V. State of U.P. ${ }^{33}$ held that under article 21, the right of life does not mean mere animal existence. Further Maneka Gandhi's Case ${ }^{34}$ laid down that a law affecting life and liberty of a person has to stand the scrutiny of article 14 and 19 of the Constitution. In other words, if a law is enacted by legislature which touches upon the life and liberty of a person and curtails it, then it is mandatory requirement that procedure established by it for curtailing the liberty of a person must be reasonable, fair and just ${ }^{35}$. It is this interpretation of article 21 which court has extended further so as to include the right to wholesome environment. In other words if pollution causes permanent disabilities leading to malfunctioning or nonfunctioning of vital organs of the body of a person then such disability may reduce him to mere animal existence and thereby deny him right to life. The question whether right to a clean environment is part of the right of life was examined by the supreme court in Subhash Kumar V. State of Bihar. ${ }^{36}$ In this case Supreme Court declared that the right to a wholesome environment formed an integral part of the right to life guaranteed by article 21 of the Indian Constitution. The Court stated:

"The right to life is a fundamental right under article 21 of the constitution and it includes the right of enjoyment of pollution-free water and air for full enjoyment of life. If anything endangers or impairs that quality of life in derogation of laws, a citizen has the right to have recourse to article 32 of the constitution for removing the pollution of water or air which may be detrimental to the quality of life. ${ }^{37}$

In this connection it will be worth to refer to Dehradun Quarry's case. ${ }^{38}$ In this case the Supreme Court entertained complaints from Rural Litigation and Entitlement Kendra, Dehradun (a voluntary organistion) alleging that the operation of limestone quarries in the Mussoorie Dehradun region resulted in degradation of the environment affecting the fragile ecosystem in the area. In this connection the Supreme Court moving under Article 32 ordered the closure of some of these quarries on the ground that these were upsetting the ecological balance, though the judgment did not make a reference to Article 21 but involving of jurisdiction by the Court under Article 32 presupposed the violation of right to life guaranteed under Article 21. This role of the Court also finds support from the observations of Justice Singh in Ganga Pollution Tanneries case ${ }^{39}$ as justifying its closure. The Court noted in conclusion: "we are conscious that closure of tanneries may bring unemployment, loss of revenue, but life, health and ecology have greater importance to the people". Besides, some High Courts have also accorded recognition to this environmental dimension of Article 21 such as judgment by the Andhra Pradesh High Court in T. Damodar Rao V. Special Officer Municipal Corporation, Hyderabad ${ }^{40}$ explicitly recognised an environmental dimension to Article 21 while considering a writ petition to enjoin the Life Insurance Corporation and Income Tax Department from building residential houses in a recreation zone, held: "It would be reasonable to hold that the enjoyment of life and its attainment and fulfillment guaranteed by Article 21 of the Constitution embraces the protection and preservation of nature's gifts without which life cannot be enjoyed. There can be no reason why practice of violent extinguishment of life alone should be regarded as violation of Article 21 of the Constitution. The slow poisoning by the polluted atmosphere caused by environmental pollution and spoliation should also be regarded as violation of Article 21 of the Constitution. The Court held that the attempt of the respondents to build houses in this area is contrary to law and also contrary to Article 21 of the Constitution". ${ }^{41}$ In the judgment of Lakshmipathy V. State of Karnataka ${ }^{42}$ the Karnataka High Court made the following observations : "The movement for restoration and maintenance of a livable environment requires curbing of power of narrowly oriented administrative agencies in appropriation of the dwindling acreage of land and water not already irrevocably appropriate", "Environment Protection is not a pre-occupation of the educated and affluent. It has a socio-political dimension. The disposal and the control of toxic waste and governmental regulation of polluting industries is public interest oriented. The effective implementation of environmental legislation is a social learning process which could fundamental change the character of public administration".

"The right to life inherent in Article 21 of the Constitution does not fall short of requirements of qualitative life which is possible only in an environment of quality. Where, on account of human agencies, the quality of air and the quality of environment are threatened or affected, the Court would not hesitate to use its 
innovative power within its jurisdiction to enforce and safeguard the right to life to promote public interest". Although the above rulings acknowledge that right to wholesome environment is implicit in the Constitutional guarantee of Article 21, but, we must acknowledge that 'right to life' is not absolute too. If the State guarantees to its citizens the security of life, the citizens must owe a duty to State to maintain its sanctity. Man has not to simply live, but to live well and living well means a living moral, virtuous and healthy and happy life. My right of living involves my duty to my fellow-men to allow them the same condition of life. Happiness and prosperity in a society is an onto function. I can enjoy my rights only if I respect the rights of others.

\section{CONCLUSION}

Man cannot lead a life of isolation. Dependence is his very psychology and individuals depend on one another and on the State as a whole. As Ernest Barker says that State has a collective life like an organism. The attainment of the common purpose therefore depends upon the proper performance by every individual of his function and duties. Every citizen has social obligations to himself, to his family, to his neighbours, and to the society of which he is a unit. So from the foregoing discussion we can say that "human life would be no where if the sacredness of this claim is not accepted. The right to life is, therefore, the most fundamental of all rights, as it is the very core of humanity. It means a claim to so live that the existence does not jeopardise the existence of others". It is not only responsibility of individual alone but State is bigger partner in preserving environment and in realistaion of right to life with human dignity. It is essential to create a shared international vision of longterm goals and to build the international frameworks that will help each country to play its part in meeting these common goals. There should be compatibility between environment and economic development. Living standards beyond basic minimum are sustainable only if consumption standards everywhere have regard for long term sustainability. Industrialized countries have an obligation to lead developing countries by shifting to sustainable development paths that would lead to significant reduction in greenhouse gas emissions; promoting aggressive research on environmentally sustainable technologies; transferring such technologies to developing countries; and making large investments in climate friendly technologies in developing countries. There should be monitoring and reporting mechanism to provide a repository for information on compliance with universally accepted norms, and a continuous and transparent effort.

\section{REFERENCES}

[1]. John W. Chapman, Rousseau, Totalitarian or Liberal, New York, University Press, 1956, p. 6.

[2]. Ibid., p. 8.

[3]. United Nations General Assembly (UNGA). (xxii), 3 December 1968

[4]. Declaration of the United Nations on the Human Environment (1972) 11 ILM 1416, Preamble and Principle 1.

[5]. Declaration of the Hague (1989) 28 ILM 1308, Preamble.

[6]. UNGA Resolution 45/94, 14 December 1990.

[7]. Resolution 1990/41, 6 March, 1990.

[8]. Draft Earth Charter, 26 August 1991; H. Hohmann (ed.), Basic Doctiivents of International Environment Law, 1992, Vol. 3, p. 1748 .

[9]. Earth Summit, Agenda 21, the United Nation Programme of Action from Rio. United Nation Publication,1993,P.9, (Sales No-E. 93.1.11; 1993).

[10]. Ibid, P-9.

[11]. Rio Principle 3: "The right to development must be fulfilled as to equitably meet developmental and environmental needs of present and future generations".

[12]. OECD, Responsibility and Liability of States in Relation to trans-frontier Pollution, 13 Environmental Policy and Law (1984), p.122.

[13]. Draft UNECE Charter on Environmental Rights and Obligations, adopted 29-31, 1990, quoted in D. Shelton, "Human Rights, Environmental Rights, and the Right to Environment", 28 Stanford Journal of International Law (Stanford California), (1991), Vol. 103 , at fn. 84 .

[14]. E. Brown Weirs In Fairness to Future Generations: International Law, Common Patrimony, and Intergenerational Equity, Tokyo 1989, Appendix B. See also Human Rights and Environment, Second Progress Report, UN Doc. E/CN.4/1993/7; the Special Rapporteur conducted an extensive study of national constitutions and jurisprudence.

[15]. UN Doc. E/CN.4/4. Sub. 2/1994/9.

[16]. A. Kiss and D. Shelton, Inlernalional Environmental law, Transnational Publications, 1991, p. 27.

[17]. Article 225 of Chapter VI.

[18]. Trolldalen, J.M., International Environmental Conflict Resolution; The Role Of The United Nations, The United Nations Institute for Training and Research, Geneva, 1992, P. 35.

[19]. Mathur, A.S., \& Chopman, K., Environmental Resources, Longman Scientific \& Technical, 1995, P. 247.

[20]. 20.Young, O., (Ed)., Global Governance: Drawing insights from Environmental Experience, MIT Press, Cambridge 1997, P. 98.

[21]. European Human Rights Reports (1991), p. 319.

[22]. Supra note 19.

[23]. Human beings are at the centre of concerns for sustainable development. They are entitled to a healthy and productive life in harmony with nature.

[24]. As revised by the Agreement signed in Mauritius on 4 November 1995. See The APC-EU Courier, No. 155 (January-Februaiy 1996).

[25]. A/CONF. 171/13/Rev 1, resolution 1, annex, chap. II.

[26]. E/CN.4/Sub.2/1994/9 of 6 July 1994. 
[27]. Recent examples are the Constitution of Ukraine, adopted 28 June 1996; Constitution of South Africa, adopted 8 May 1996; Constitution of Euthopia, adopted 8 December 1994; Constitution of Argentina, adopted 23 August 1994.

[28]. Supreme Court of the Philippines, Manila, 30 July 1993, Minors Oposa V. Secretary of the Department of Environment and Natural Resources, G.R. No. 101083, reprinted in 33 ILM 173, 187 (1994).

[29]. Report of the WHO Commission on Health and Environment, World Health Organization, Geneva, 1992.

[30]. D.D. Bassu, Introduction to the Constitution of India, New Delhi, Prentice-Hall of India Pvt. Ltd., 1994, p. 141.

[31]. Dr. S.N. Dhyani, Fundamentals of Jurisprudence, Allahabad-2, Central Law Agency, 1997, p. 367.

[32]. AIR 1950, SC 27.

[33]. AIR 1963, SC1295.

[34]. AIR 1978, SC 597,

[35]. Francis Coralie Muliin V. The Administrator of Delhi, AIR 1981, SC 746.

[36]. Subhash Kumar V. State of Bihar, AIR, 1991, SC 420.

[37]. Ibid.

[38]. Rural Litigation and Entitlement Kendra, Dehradun V. State Uttar Pradesh, AIR, 1985, SC 652, AIR 1988 SC 2187.

[39]. M.C. Mehta V. Union of India, AIR 1988 SC 1037.

[40]. AIR, 1987 AP 171.

[41]. Ibid., 181

[42]. AIR, 1992 Karnataka 57. 